\title{
INCOME-GENERATING PROJECTS: ALLEVIATING OR PERPETUATING POVERTY?
}

\author{
Raisibe Kaeane, Eleanor Ross
}

\section{INTRODUCTION}

\section{Poverty in South Africa}

Following the first democratic elections in 1994, South Africa experienced a shift from an apartheid-based state to a democratic, egalitarian society, a shift which took place in the context of globalisation. Among the structural injustices inherited from the apartheid system, poverty is particularly prominent and compounds all others. The existence of a socially conscious government in South Africa has firmly placed the need to address poverty high on the nation's agenda. Policy development and resources set aside by government are testimony to the fact that the government is committed to providing a better life for all by fighting poverty (Mubangizi, 2004).

However, Patel (2005) points out that despite the government's poverty-alleviation efforts, poverty remains one of the greatest challenges facing South Africa and is reflected in low levels of income and high levels of human deprivation, underdevelopment and marginalisation confronting those caught within the second or informal economy. A considerable number of South Africans, estimated to be in the region of $57 \%$ of the population, are living below the poverty line, despite initiatives to eradicate poverty.

Moreover, those living in poverty have sunk deeper into poverty and the gap between the poor and the rich has become wider (Strydom \& Tlhojane, 2008). While South Africa is generally categorised as a middle-income country, South Africa is regarded as an extremely unequal society with its Gini coefficient having risen from 0.596 in 1995 to the unacceptably high level of 0.679 in 2009 (Development Indicators, 2009) and its Human Development Index having fallen from 0.73 in 1995 to 0.683 in 2007, but expected to increase with the roll-out of antiretroviral treatment (SAIRR, 2011). South Africa's Service Index, which measures the percentage of the population that does not have access to good-quality basic services, has increased from $63 \%$ in 1996 to $65 \%$ in 2003. This accounts for the fact that in spite of its relative wealth compared to the world's poorest countries, there are indeed vast and growing levels of poverty experienced by large numbers of South Africans (Holscher, 2007).

The April 2011 Quarterly Labour Force Survey (Statistics South Africa, 2011) places unemployment figures at $25 \%$ of the adult working-age population. Although a $0.3 \%(42,000)$ annual employment increase was recorded compared to the first quarter of $2010,0.7 \%(31,000)$ more people were recorded as unemployed, and 486,000 (3.4\%) more people were recorded as not economically active, of which 353,000 were categorised as "discouraged work seekers" (Statistics South Africa, 2011). At the same time employment does not guarantee people's ability to move out of income poverty. In addition, income poverty is distributed unevenly according to lines of race, gender and geographic location, in that the face of poverty in South African is predominantly female, rural and black (Sachs, 2005). However, the absence of a national poverty line has been seen by many social policy analysts as an impediment towards achieving a unified understanding of poverty in South Africa and an obstacle to progressive social dialogue (McLennan, 2007). 


\section{Public responses to poverty in South Africa}

In order to address the legacy of South Africa's colonial and apartheid history, the government has adopted a transformative, developmental framework and is moving towards becoming a developmental state. One of the government's responsibilities is to facilitate the process of development through the various institutions of government, its partners and civil society. Given the country's history, a central priority of government, as required by the Constitution's Bill of Rights, is to ensure provision of a range of services to meet developmental challenges, within the constraints of available resources.

From 1994-1996 the Reconstruction and Development Programme (RDP) became the paradigm within which all development policies were discussed and the guiding document of the Government of National Unity (Visser, 2004). In 1996 the Growth, Employment and Redistribution (GEAR) policy was implemented. GEAR was a neoliberal, macroeconomic policy designed to contribute to the economic development. GEAR implied that economic development in South Africa should be led by the private sector, the state should play a smaller role in the economy, there should be cuts in government spending, an export-orientated economy should be encouraged and social service delivery budgets should be reprioritised to address the claims of the poor to meet their basic needs. The GEAR strategy would appear to be partly responsible for the current social crisis, because growth through redistribution was replaced by redistribution through growth (Bond, 2003).

\section{Integrated developmental social welfare in South Africa}

Against this background, and in recognition of the need to promote the goals of sustainable development to redress the country's unique history of inequality and violation of human rights due to colonialism and apartheid, the social service sector adopted the White Paper for Social Welfare in 1997. This policy document put forward the concept of a developmental approach to service delivery which transcends the residual welfarist approach that dominated social welfare thinking in the past, and endeavoured to integrate social interventions with economic development (Integrated Service Delivery Model, 2006). The ideas surrounding the conception of developmental social welfare in South Africa are enshrined in the Constitution of the Republic of South Africa Act of 1996 (Department of Social Development, 2011). These ideas are rooted in what Patel (2005) calls a rights-based approach which is derived from the principle of inequality and the need to redress the unfair distribution of resources, and to provide a service that is equitable, sustainable, accessible, people-centred and developmental.

The social development approach aims at collective empowerment, facilitating processes that help the poor, vulnerable and marginalised to regain control over their lives (Integrated Service Delivery Model, 2006). This model encourages the use of social programmes, but with the focus on enhancing capacities of the needy by affording them an opportunity to participate in the productive economy (Midgley, 1995). Social development is also defined as a process which involves the participation of all stakeholders in decision-making, fostering self-reliance, the harnessing of the efforts of all individuals, the development of a sound network of institutions and the promotion of harmonious relations between individuals, communities and their physical environment (Patel, 2005). Developmental social welfare focuses on social protection and the maximisation of human potential and has a particular focus on the causes and effects of social vulnerability and marginalisation. 


\section{Challenges confronting the Gauteng Department of Social Development}

One of the leading roles of the Department of Social Development is to provide a safety net for the vulnerable. In addition, the Department is faced with the challenges of reducing the levels of poverty prevalence that impact on social functionality and development of families and communities (Department of Social Development Five Year Strategy, 2006-2010). These challenges are exacerbated by increasing migration from other countries and provinces to Gauteng; increased drug trafficking and drug abuse linked to organised crime; a high prevalence of HIV and AIDS; and non-inclusion of people with disabilities within communities (Department of Social Development Five Year Strategy, 2006-2010).

In the light of the above challenges, the Gauteng Provincial Government (GPG) aligns itself with the Millennium Development Goals (MDGs) by aiming at halving poverty and unemployment by 2015, providing skills required by the economy and ensuring that all South Africans are fully able to exercise their constitutional rights and enjoy the full dignity of freedom (Department of Social Development Five Year Strategy, 2006-2010).

The Department of Social Development renders services through three broad programmes, namely social security, social welfare and community development. Social security services aim at providing the target groups with social grants as a way of alleviating poverty. Social welfare services cover a range of services and programmes that are directed at enhancing the capacities of people to address the causes and consequences of poverty vulnerability. With a shift to the social development approach, a new cadre of community or social development officers/workers was introduced to focus on community development which is aimed at enhancing the capacity of communities to respond to their own needs and improve their capacity for development, through community mobilisation, strength-based approaches and empowerment programmes (Integrated Service Delivery Model, 2006). Ideally, these programmes should be integrated and should enable the target groups to deal with all social issues such as psychological stress, poverty, food security and other adverse social conditions (Department of Social Development, 2006).

However, the global economic slowdown and food security crisis are impacting directly on efforts to reduce poverty and achieve the MDGs (Millennium Development Goals Report, 2008). The Millennium Development Goals Report (2008) recommends that public investment and public institutions should endeavour to target the poor and particular attention should be paid to the creation of additional opportunities for decent work.

\section{Poverty-alleviation programmes}

Since 2003 the Department of Social Development has formulated a new strategy for alleviating poverty, through the component Sustainable Livelihoods. Sustainable development is not only concerned with the needs of the present generation, but present efforts in developing communities should not compromise the survival of future generations (World Bank, 1992). Although sustainable development is sensitive to the environment, it is also concerned with programmes that promote the social and economic welfare of the citizens, and the interdependence of the social, economic and environmental objectives in the development process (Noyoo, 2003).

A Development Centre model was formulated as one of the poverty-alleviation strategies aimed at empowering South Africans towards achieving self-reliance, and implementation takes place at regional level. A Development Centre refers to multi-purpose, non-profit, communitymanaged organisations which are funded by the Department of Social Development, whose 
objectives are to implement various poverty-alleviation programmes such as skills development, income generation, social programmes, and information and referral programmes (Department of Social Development, 2006). Income-generating projects are projects where beneficiaries come together in groups after they have gone through skills-development training by the Development Centre. Beneficiaries collaborate with the aim of establishing a small business, through which the Development Centre is able to exit them with a small amount of funding in the form of a start-up pack. There needs to be a clear exit strategy on entry for mobility of beneficiaries from the time when they enter the Development Centre. Beneficiaries should ideally make use of the services rendered and then move to the next level of selfreliance and independence.

The government's anti-poverty strategy involves utilising community development workers, social workers, community and home-based care workers, constituency offices, counsellors and non-governmental organisations (NGOs) in identifying households and individuals in dire poverty and providing one or a combination of interventions already available, such as social security, agricultural starter packs, micro finance and small, medium and micro enterprise (SMME) assistance, and enrolment in the Extended Public Works Programme which seeks to "provide unemployed individuals and volunteers with a stipend, on the job experience as well as training for a period" (Plaatjies \& Nicolaou-Manias, 2005:8).

Poggenpoel and Oliver (2005, cited in Holscher \& Sewpaul, 2006) conducted a study on service users and departmental spending with regard to poverty-relief programmes. They claim that $82.3 \%$ of service users seeking help at government welfare offices do so in relation to social grants, $22.1 \%$ request individual assistance by social workers and only $2.4 \%$ call in connection with poverty-relief projects. These findings are supported by Sewpaul and Holscher (2006), who contend that statutory services and institutional care continue to constitute the bulk of welfare work. Rendering of developmental services such as facilitation of povertyalleviation projects remains minimal.

According to Poggenpoel and Oliver (2005, cited in Holscher \& Sewpaul, 2006), the Department of Social Development has been unsuccessful in spending its allocation of the poverty-relief budget appropriately. These writers maintain that unless efforts are made to include the poor in the delivery process, it is possible that poverty-alleviation programmes will turn out to be programmes run without beneficiaries' input into the conceptualisation, implementation and evaluation process. A direct result of this scenario is that povertyalleviation programmes are unlikely to address the relevant issues, nor will they empower the poor to any level that removes them from, or substantially alleviates, poverty (Mubangizi, 2004). However, this criticism cannot be generalised to the whole array of South African income-generating projects.

Zungu (2006) explored factors contributing to the success or failure of income-generating projects in Nongoma, KwaZulu-Natal by focusing on four case studies of income-generating projects for comparative purposes. The main findings from his research were that successful community development projects helped poor women in rural areas to earn a living through income-generating activities. These poor women became self-reliant and self-sustaining. The present study endeavoured to expand and build on Zungu's (2006) research by focusing on persons who had participated in income-generating projects in the Sedibeng region, Gauteng province and probing different issues. 
Based on experiences of the first author in working with Development Centre beneficiaries, observations were made regarding the kind of projects in which beneficiaries were engaged. The impression gained was that it usually takes a relatively long time before beneficiaries can start generating an income from projects, and if income is generated, beneficiaries often do not derive adequate income from that source. It was against this background that a need was identified to determine the beneficiaries' perceptions of income-generating projects in Departmental poverty-alleviation programmes. The main aim of the study was to investigate beneficiaries' perceptions of income-generating projects at Gauteng Department of Social Development: Sedibeng Region. Specific objectives were to assess whether the Development Centres were perceived to be an appropriate response to poverty alleviation; whether incomegenerating projects within the Development Centres were perceived by beneficiaries as making an impact on the quality of their lives; challenges encountered by beneficiaries during the implementation of the projects; perceived effectiveness of Development Centres as a service delivery model; and to elicit their recommendations for future interventions and ways of enhancing service delivery and implementation of projects.

It was anticipated that the study would allow the voices of participants to be heard and involve them in evaluating poverty-alleviation programmes and identifying possible gaps in service delivery, thereby enhancing knowledge and understanding of the needs and challenges experienced by beneficiaries and stimulate further discussion on poverty-alleviation strategies.

\section{METHODOLOGY}

\section{Research strategy}

This study adopted an exploratory-descriptive research design located within a qualitative paradigm. Williams, Unrau, Grinnell and Epstein (2011:53) maintain that "the qualitative research approach is based on the interpretive perspective, which states that reality is defined by the research participants' interpretations of their own realities".

\section{Participants}

A sample of 20 participants comprised beneficiaries who participated in income-generating projects at the Development Centres called the African Skills Development (ASEDI) (Bophelong) and Kotulong (Meyerton) funded by the Department of Social Development. The 20 participants were all Black Africans and had participated in the centre projects for longer than a year. They participated on a voluntary basis.

\section{Sampling strategies}

Non-probability purposive and convenience sampling was used. The researcher relied on Centre managers to provide access to participants; consequently only those who were available in their units at the particular time when the researcher was present participated in the study. Although some of the results may have been applicable to other settings, the small, nonrepresentative, sample precludes generalisation of the findings to the broader population of beneficiaries participating in income-generating projects.

\section{Research instrumentation}

A semi-structured interview schedule was designed to explore the perceptions of participants in income-generating projects. The interview schedule was divided into four sections, namely demographic details of participants; perceptions regarding income-generating projects; the 
perceived impact of income-generating projects on the quality of life of the beneficiaries; and participants' recommendations on how poverty-alleviation strategies could be implemented.

Efforts were made to enhance content and face validity by referring the instrument to an expert in the field from the Department of Social Development, who confirmed that the range of items included in the instrument appeared to demonstrate content and face validity. In order to further enhance validity of the instrument, the research tool was pre-tested on three individuals who were not included in the final study. All the participants indicated that they understood all the questions, hence no amendments were necessary. The researcher endeavoured to enhance reliability by personally administering the same questions in the interview schedule to all the participants in the research study.

\section{Data collection}

The study was conducted in two Development Centres based at Sedibeng region within Gauteng province. The researcher was introduced to the participants in their workshop rooms, where the project participants engaged in manufacturing goods. She explained her reason for being there as well as the aims of the research and the potential risks and benefits of participation. After obtaining informed consent, the interview schedule was administered individually to participants in the privacy of the boardroom. Data were collected by interviewing the participants using both English and various African languages, so that they would be able to express themselves in the language of their choice. Their responses were written down by the researcher.

\section{Data analysis}

Data were analysed using thematic content analysis, which involves counting the frequencies and sequencing of particular words, phrases or concepts in order to identify keywords or themes (Welman, Kruger \& Mitchell, 2008). In undertaking the thematic analysis the following steps were followed and were adapted from Terre'Blanche, Durrheim and Kelly (2006) namely, (1) familiarization with and immersion in the data through re-reading the responses; (2) inducing themes and coding by grouping common views or statements together; (3) elaboration by re-examining the themes established earlier and exploring them in greater depth; (4) interpretation and checking where contradictions or over-simplifications of the data were noted and explained.

Member checking was used to confirm the findings, whereby the researcher went back to the original participants and asked them to confirm that the issues and themes that she had identified were a true reflection of their responses. In addition, and in order to reduce subjectivity, correspondence checking recommended by Pretorius and De la Rey (2004) was undertaken. This procedure involved the use of an independent rater to analyse the categorisation of data and compare the analysis of themes by the primary researcher to check for correspondence.

\section{Ethical considerations}

The ethical principles taken into consideration included avoidance of harm to participants; informed consent; voluntary participation and the right to withdraw from the study; avoidance of deception, coercion and perverse incentives; confidentiality; approval of the study by the relevant university ethics committee; and obtaining permission from the Department of Social Development. 


\section{RESULTS AND DISCUSSION}

\section{Profile of participants}

TABLE 1

SOCIO-DEMOGRAPHIC PROFILE OF PARTICIPANTS (N=20)

\begin{tabular}{|l|l|c|}
\hline Demographic Factors & Sub-Category & Number of Participants \\
\hline Gender of participants & Male & 6 \\
& Female & 14 \\
\hline Race & African & 20 \\
& Other & 0 \\
\hline Age distribution & $20-30$ years & 8 \\
& $31-40$ years & 5 \\
& $41-50$ years & 5 \\
& $51-60$ years & 2 \\
\hline Level of Education & Primary & 3 \\
& High School & 14 \\
\hline Beneficiaries having people depending on & Tertiary & 3 \\
them financially & Yes & 18 \\
\hline
\end{tabular}

Table1 shows that the majority of the participants were female. This finding was not expected, given the fact that often women are expected to be at home, caring for their children. The predominance of African people in the sample could possibly be explained in terms of Du Toit (2006), who argues that with the lifting of racial restrictions on where people could live and work, many unemployed people (predominantly Blacks) migrated to the major cities only to be faced with unemployment and all its hardships. Nevertheless, the implication of this finding is that community awareness programmes regarding Development Centres need to reach a wider audience so as to broaden access to these Centres.

A total of 20 participants aged between 22 and 60 years were interviewed and of those $8(40 \%)$ of the participants were between the ages of 22 and $30,5(25 \%)$ of the participants were between the ages of 31 and 40; $5(25 \%)$ were between the ages of 41 and 50 and $2(10 \%)$ were between the ages of 51 and 60. Their mean age was 33.6 years with a range of ages from 22 and 60 years. The majority $14(70 \%)$ of the participants had a high school education, $3(15 \%)$ had primary education and $3(15 \%)$ had tertiary-level education. This finding suggests that beneficiaries at the Development Centres were not illiterate and that unemployment could be the main reason for participation in the income-generating projects. The majority $18(90 \%)$ of participants had people depending on them financially, indicating that generation of income at the projects was a crucial survival strategy for beneficiaries at the Development Centres and their dependants.

\section{Perceptions regarding income-generating projects}

Participants appeared to have a clear understanding of the projects and the government objectives for such initiatives. Analysis of responses revealed the following three themes: 


\section{Projects designed to empower people with business skills}

Eight participants perceived that income-generating projects were designed to empower people with business skills. One gentleman in his early thirties explained: "They are projects to assist people with opening their own businesses in future". Another participant stated: "These projects are designed to empower people with business skills."

\section{Income-generating projects as an unemployment strategy}

Seven out of the 20 participants described income-generating projects as a strategy that government used to fight unemployment. They also seemed to have a good understanding of the projects. Illustrative comments included: "Department wants to assist unemployed communities to have opportunities that assist them to have income" and "Purpose is to fight poverty and for self-employment". Another person commented: "I think they were created to create jobs and take people away from crime".

\section{Strategy of government to fund job creation and raise the standard of living}

Five of the participants felt that this was simply a government strategy to provide people with funding to improve the standard of living amongst the poor and at the same time create jobs. Verbatim responses that captured this theme included: "With this projects government was trying to come with a strategy to help people so that people can take care of their needs. Its efforts by the department for people to be able to support themselves and I think it's something that helps you to get training and light in life".

However, it was interesting to note that out of the 20 participants, two thought that the strategy was primarily meant for Black people. The following represent their comments: "Projects to alleviate poverty by the department, skills development, income generation and the target group is for Black people" and "Something that helps Black people through government to get business opportunities".

The aforementioned responses were in line with the government strategy for all the Department of Social Development's programmes to address the priority needs identified by the Premier-inExecutive on 4-6 May 2004, namely "fighting poverty and building safe, secure and sustainable communities". According to the Revised Operations Manual for Development Centres (Department of Social Development, 2007), poverty programmes are partly a matter of improving income and partly a matter of restoring human dignity and achieving equality. Even though some beneficiaries believed that the income-generating projects were meant specifically for Black persons, the guiding principles underpinning the Development Centre programme are that programmes must target the most vulnerable groups and impact on the lives of the community as a whole (Department of Social Development, 2007).

\section{Reasons that led beneficiaries to participate in income-generating projects}

When responses regarding reasons that led beneficiaries to participate in income-generating projects were analysed, three main themes emerged, namely to gain skills and knowledge, to reduce unemployment, and because they were recruited by a community member and/or friend.

\section{Gaining skills and knowledge}

It was noted that the majority of the participants 15 (75\%) were recruited by community members and wanted to acquire skills and knowledge. 


\section{Reducing unemployment}

Unemployment was also a reason that motivated some of the participants $6(30 \%)$ to participate in the income-generating projects. For example, one individual informed the researcher that he was unemployed with no income to maintain his family. "I was unemployed and just sitting at home without food on the table so I started volunteering my services at the centre". Another participant gave the following reasons for participation: "I was unemployed with matric and lack of money to further my studies".

Swanepoel (2007) argues that unemployment is both a cause and a result of poverty. It is a cause because without a job, a person has no income and cannot afford to pay for proper housing, food, medical care and education for his/her family. The White Paper on Social Welfare (1997) acknowledges that individuals, families and communities become more vulnerable to poverty during times of unemployment. It is generally known that unemployment has devastating effects on the lives of people. Unemployment also exerts a negative psychological impact by making people perceive themselves as redundant.

\section{Recruitment by community member or friend}

Three $(15 \%)$ of the participants initially came to assist but subsequently developed an interest in the projects. They articulated the following reasons for being at the Centres: "I like to work with my own hands. From the time I heard about the centre I became interested and started coming and Somebody from the community knew that I have since been involved in projects and she asked me to come and assist with projects. Since then I became one of the beneficiaries". Another participant commented: "I had a small business at the same time training other people. In the process I got divorced and left everything. A friend told me about the centre which I thought I will just keep myself busy".

In this respect community involvement in projects is crucial as it is stated in Allred's (1998) writings that sustainability of development projects can be achieved if the community is involved in the entire planning and implementation process. In this case implementation involves projects being discussed in communities for others to be recruited. Paul (1987) maintains that the community as the beneficiary influences the direction and execution of development projects.

\section{PERCEPTIONS REGARDING THE ADVANTAGES AND LIMITATIONS OF INCOME-GENERATING PROJECTS}

\section{Advantages}

With respect to what they found particularly good or satisfying about income generating projects, the following themes emerged, namely development of skills and knowledge, and poverty alleviation. These themes indicated that beneficiaries had a clear understanding of the good intentions behind the income-generating projects developed by government.

\section{Development of skills and knowledge}

Sixteen of the 20 participants, constituting the majority, stated that development of skills and knowledge were the most important features of the income generating projects. The following verbatim responses encapsulate this theme: "They give poor people skills to be able to support themselves. They assist illiterate people to have skills and be able to look for jobs like educated people; To remove people from townships, get skills and open own business and other people". These quotes indicate that in terms of skills and development, the Development Centres were perceived to be achieving the set objectives from the Revised Operations Manual for 
Development Centres, which states that poverty is often manifested in a lack of skills and knowledge to address needs. However, the manual indicates that the training provided at the Centres should be accredited as far as possible and provide beneficiaries with a certificate that would give them an opportunity to obtain formal employment (Department of Social Development, 2007). Consequently, a limitation of this study was that it did not explore whether training that was provided was indeed accredited and whether certificates were provided.

\section{Alleviation of poverty}

Alleviation of poverty was described by four participants as the outstanding feature of the income-generating projects. One of the participants commented: "They create jobs for the unemployed and lessen poverty". According to Dimitrievska (2008), poverty alleviation/reduction is partly a matter of improving income and partly a matter of restoring human dignity and achieving equality. Poverty alleviation at the Development Centres includes restoring the sense of security that living in a particular context brings and provides choices that allow people to develop a better quality of life (Millennium Development Goals Report, 2008).

\section{Limitations}

\section{Start-up funding is very limited}

Twelve of the participants felt that the funding provided was very limited and did not cover certain basic needs of the projects. Furthermore, restricted funding hindered the ability of the projects to grow from the ground. The following responses illustrated this theme: "What is not good is not to get financial assistance at the right time and Leaders without same financial vision as beneficiaries about the projects".

\section{Lack of financial skills on the part of beneficiaries}

Nine beneficiaries mentioned that even though skills were provided, they did not have proper financial management skills to be able to take their small businesses from a start-up level to the level of profit-making businesses.

\section{Expectations from the funders not clearly articulated}

Eight participants stated that they had expected that the Department was giving the participants jobs with remuneration through income-generation projects. However, it subsequently emerged that beneficiaries were expected to receive only training through skills development, develop their own businesses and create jobs for others. "Communication is not open with funders, not everybody knows what the expectations from the funder are".

\section{Projects not fully accessible by all within communities}

Seven participants stated that the projects only targeted a small number of people from the communities. Each project had a number of beneficiaries ranging from five to a maximum of eight. The total number of beneficiaries at each centre ranged from 30 to 50, as opposed to thousands of community members who were unemployed.

\section{Lack of proper monitoring and planning from the Department}

Seven of the participants complained that social workers who were responsible for monitoring projects did not monitor appropriately, did not visit regularly, did not read monthly reports that outlined projects' challenges, and did not provide support for the projects. Instead, they tended to support the Development Centre and they regarded their partner as the Centre only. This 
theme was captured in the following responses: "I think that the Department does not plan and monitor the projects properly. There are a lot of problems that we raise through reports and There is no proper monitoring from the Department and the Development Centre to ensure sustainability".

\section{Types of businesses not being able to compete in big business markets}

Six of the participants stated that the types of businesses that were encouraged were not suitable for competing in big markets and creating jobs for other people as was expected. This meant that beneficiaries were not given the freedom to choose the type of projects they wished to explore. Instead, the Department was prescriptive in terms of the type of projects to be run. One of the verbatim responses that highlighted this theme included the following: "What I don't like about this is that they decide on type of projects and still those projects that they choose are unable to produce a lot of money, and the products that come from the projects cannot compete with products from big stores".

\section{Scope of projects and target participants very limited}

Five participants felt that targeted numbers were very low and, consequently, if government was serious about poverty alleviation, it needed to increase the uptake of people at Development Centres as well as the range of skills offered. "It's frustrating for me to be not able to manage finances. I think the projects will die if no one has training on finances. End of the month what they want is reports with expenditures, they also don't give feedback whether things were done correctly or not",

\section{Recommendations regarding changing of projects}

When asked if there was anything they would like changed in the income-generating projects, $14(70 \%)$ stated that they would employ good managers at the Centres and provide support and leadership to beneficiaries. They also mentioned that they would train social workers in terms of skills and knowledge about monitoring of income-generating projects. Six (30\%) of the participants indicated that they would provide sufficient funding to start a business and train beneficiaries in financial management before allocating funding. One of the participants stated: "Social workers do not know what are the steps involved to have a completed product like bread in terms of baking or trousers in terms of sewing projects. All they are interested in is reports, expenditure and whether we making profit or not".

This finding was consistent with findings obtained by Zungu (2006) on factors contributing to successes and failures of income-generating projects. He found that social workers tended to focus on financial statements and proof of expenditure. Zungu (2006) emphasises that there needs to be close monitoring of how funding is spent; however, development is not only about income generated and expenditure incurred in the projects. Development of human capacity is also important and occurs through giving feedback about where the project members have done well and pointing out where they need to improve.

\section{Skill capacity improvement since participating in the income-generating projects}

The majority i.e. 18 (90\%), of participants were of the opinion that their skill capacity had improved dramatically. Twelve $(60 \%)$ of the beneficiaries who felt that their skills had improved stated that much effort and time was invested in training at the respective projects. Fifteen $(75 \%)$ beneficiaries who participated in bakery, toilet-paper making and sewing at the two centres were most satisfied with the skills they had acquired. According to Zungu (2006), the type of training is crucial in determining the success or failure of income-generating 
projects. This focuses on the expressed and felt needs of the service users and the quality of products made by the income-generating projects.

Fifteen participants stated that they were very thankful to the Department for their improved skill capacity, as this enhanced their job performance. This finding is understandable if one considers that baking, toilet-paper making and sewing are projects that are relatively active in terms of production, and income is generated from these projects. A few, i.e. 2 (10\%), of the participants stated that their skill capacity did not improve since participating in incomegenerating projects. They explained that this lack of skill development was because they were provided with training that was irrelevant to their project and because they were not yet sure what to do with their projects as they were not very active. One participant reflected: "I was provided with training on how to do canned fruits. Remember I'm involved in agricultural project. I was not trained on how to prepare the soil. Our project was not even given funding for water so that we can work on the land properly".

\section{THE PERCEIVED IMPACT OF INCOME-GENERATING PROJECTS ON QUALITY OF LIFE OF BENEFICIARIES}

\section{Significant changes before and after participation in the income-generating projects}

When asked whether there was any significant change before and after participation in the income-generating projects, $18(90 \%)$ of participants agreed that their participation in incomegenerating projects did bring significant changes to their lives. Two thirds, i.e. $12(60 \%)$, stated that their skill level had improved, they now had income for their basic needs and their stress levels had decreased. Only a few, i.e. 2 (10\%), were of the opinion that their participation in income-generating projects did not bring any significant change in the quality of their lives. On being asked to elaborate, one participant stated that the project in question did not generate any income; hence no significant change could be seen since participating in the income-generating projects. These findings underscore the need for the development of more market-driven projects that will fill a gap in the market and are likely to generate income for participants.

\section{Ability to maintain dependants from income received}

Thirteen persons $(65 \%)$ indicated that they were able to maintain their dependants from the income generated from the projects, while seven $(35 \%)$ were not able to do so. Those who answered in the affirmative explained that even though they had an income to maintain their dependants, the income was not sufficient for most of their needs, or to maintain the lifestyle that they would prefer. They further stated that there was nothing they could do to change their present circumstances as their businesses were still developing and the funding provided was limited.

\section{Changes in quality of life since participating in the income-generating projects}

Fifteen $(75 \%)$ stated that the quality of their lives had changed since participating in incomegenerating projects and that at the time of the study they were more business-minded, they took greater care of themselves in terms of the provision of basic needs, and their personal financial management had improved. This finding suggested that the learning acquired in respect of the financial management training had been transferred to the participants' other life domains. This appeared to have brought personal fulfilment to $12(60 \%)$ participants, as they also had been afforded the opportunity to meet new people, establish contacts and build relationships with strangers. Five $(25 \%)$ participants felt that their lives had not yet changed. It was interesting to 
note that their response was not "no" but rather "not yet", suggesting that participants were still hopeful that with future participation the quality of their lives might improve.

\section{Beneficiaries' views regarding reasons for future participation in other income- generating initiatives}

A total of $13(65 \%)$ participants indicated that they would participate for the reasons set out in Figure 1.

FIGURE 1

BENEFICIARIES' VIEWS REGARDING REASONS FOR FUTURE PARTICIPATION IN OTHER INCOME-GENERATING INITIATIVES $(\mathbf{N}=\mathbf{2 0})$

Further improve their skill and knowledge
Expand the present business
Exposure to additional opportunities

\section{Further improve skills and knowledge}

As depicted in Figure 1, $8(40 \%)$ of the participants stated that they would participate in other initiatives mainly in order to improve their skill and knowledge. One participant commented: "Maybe it may be different to this and that will depend on its scope and whether it will further my knowledge and skill on what I have”.

\section{Personal growth}

Four $(20 \%)$ of the participants stated that their desire for personal growth would be the main reason for participating in future poverty-alleviation initiatives from other government departments. Verbatim responses that captured this theme included: "Yes, I want more opportunities; I want growth as a person. I want learn more and benefit more. I love agriculture and I want to improve myself more and I want to implement what I have learnt".

\section{Exposure to additional opportunities}

Four $(20 \%)$ of the participants felt that other poverty-alleviation initiatives would be seen as additional opportunities not to be missed that could potentially yield positive outcomes. One participant mentioned: "Yes, I want to be able to gain more knowledge and to have more skills that would expose me to more opportunities. When one learn a lot, one gets more opportunities". 


\section{Expand the present business}

Four $(20 \%)$ of the participants explained that they would participate in order to expand and benefit their present businesses. Verbatim responses that reflected this theme included: "I am a hard worker. I want my business to expand and Yes, if it will benefit my project - why not".

Seven $(35 \%)$ participants explained that they would not participate in poverty-alleviation initiatives from other government departments. The main reasons for this response were that participants were quite content with what they had acquired and they felt that they had invested a lot of energy and time in what they were presently doing in their businesses. They also explained that instead of exploring other initiatives, they would rather focus on developing and expanding their current business ventures.

\section{RECOMMENDATIONS}

In line with the qualitative approach, participants were asked to make recommendations for enhancing the implementation of poverty alleviation strategies.

\section{Whether income-generating projects were perceived as the best way to alleviate poverty}

Nineteen (95\%) of the participants thought that income-generating projects were the best way of alleviating poverty, while only one $(5 \%)$ felt that this was not the ideal way to eradicate poverty. Of those who felt that the income-generating projects were the best way of alleviating poverty, twelve $(60 \%)$ elaborated by saying that this strategy was beneficial, because people were given skills to generate their own income. Six participants explained that the strategy was helpful because the government was trying its best to lift people out of poverty. One participant gave the following response to illustrate the fact that the strategy was working: "As a young person I have been empowered to take responsibility for my own life". Another participant commented: "The strategy is very good and if explored properly small projects can run to be massive production companies and more jobs can be created". One participant who felt that this was not the best strategy explained that the process of income-generating projects took too long to lift people out of poverty. Four participants further stated that people want jobs to survive and not to be involved in projects to create jobs for others.

\section{Recommendations from participants on how to improve future interventions and service delivery}

\section{Recommendations for Development Centres}

Seven participants recommended that the target population of Development Centres needed to increase to include more people, if they were serious about poverty alleviation. Development centres were also requested to provide strategic leadership in terms of objective management of projects. There was a general concern about communication, support and openness from the Development Centres. The following were some illustrative comments from the beneficiaries: "The Centre does not respect us as beneficiaries in terms of our needs and demands. No support is received from the Centre in terms of what we want to develop projects. Centre is not prepared to support us. There's lack of commitment from the Centre. Department must ensure that there's proper communication between the Development Centre and the projects especially on management of funds".

Four participants recommended that the Centres give them monthly financial reports on how funding was spent. There was a general concern from the same participants that projects are 
made to be accountable to the Centre on how they run the projects and participants were not happy with the requirement. It was also recommended that project personnel sign the servicelevel agreement with the Department.

These findings illustrate the importance of listening to the voices of the beneficiaries at the centres. It is envisaged that with proper guidance and active involvement of the beneficiaries in stating clear objectives, income-generating projects can potentially generate positive results in the lives of the poor, as people are generally very eager to participate in any project that may meet their needs.

\section{Recommendations for Department of Social Development}

As the Department was the funder of both the projects and the Development Centres, five participants recommended that the Department assess and evaluate projects continually to ensure that people were satisfied and making good progress. It was felt that the Department needed to create more Development Centres to target more people, if they were serious about poverty alleviation. At the time of the study in Sedibeng the Centres could not accommodate even a quarter of the population within the surrounding communities. Sedibeng has a population of 796754 inhabitants (South African Survey, 2007/08) and only about 100 beneficiaries participate each year. There was a general concern about funding: participants felt that the funding provided was insufficient and that money should be deposited in the projects' account rather than the Centres exercising control over the funds. One beneficiary commented: "Department must fund based on what we have requested not on what they have. We estimated R1.5 million and they only gave R450 000 of which R150 000 was for the truck, R250 000 was for the machine, R20 000 for office equipment and R10 000 for running costs. Basically there is no budget for raw material and there is no way that we can run a sustainable business on such an amount".

This finding on insufficient funding provided by the Department was similar to the findings from the study conducted by Zungu (2006:24) with income-generating projects in Nongoma, KwaZulu-Natal. He stated that "The beneficiaries experienced serious problems in delivering their blocks to their customers and needed a tractor to reach people. In 1999 they were granted R42 000.00 by the Department of Social Development and a further grant of R90 000.00 by the Department and as a result they were unable to purchase a tractor".

Another general concern that was raised was around the relationship between the Centres and the projects. Participants recommended that the service-level agreements be signed with the project participants and not with the Centres, as projects are also important partners and those projects could be recognised by other stakeholders and financial institutions. Another recommendation was that the Department needed to assist participants to have their projects approved by South African Bureau of Standards (SABS) to be able to compete in big markets. Participants felt that the ideas for projects and cooperatives were underestimated by the Department and that proper analysis was not conducted prior to implementation.

\section{Screening of potential beneficiaries}

There was a general concern from four participants from the two Centres regarding the way in which beneficiaries were recruited to participate at the Centres. The majority of the participants, i.e. $15(75 \%)$, were recruited by community members and wished to acquire skills and knowledge. Unemployment was also a factor that motivated some of the participants $(6 / 30 \%)$ to participate in the income-generating projects. Very few $(3 / 15 \%)$ of the participants came simply to assist and subsequently started to develop an interest in the projects. However, 
a limitation of the study was that the researcher did not explore whether potential beneficiaries were screened prior to participation in the projects. In this respect Zungu (2006) states that the services rendered by the projects should target the correct beneficiaries to improve the chances of successful implementation.

Participants stated that identification of beneficiaries needed to be more efficient, and that screening and interviews needed to be conducted to assess the level of interest and abilities of the beneficiaries so that proper placement into different projects could take place. The other recommendation was that beneficiaries should be told from the outset that the Centre was simply an incubator and that beneficiaries would have to exit at the end. One participant stated: "I was only taught on how to manufacture a toilet paper but I was never told at the beginning that an expectation will be to sell the same toilet paper to the market, which involves a very difficult process". This finding suggested the need for terms of references to be communicated clearly to beneficiaries during admission. Participants also emphasised that beneficiaries at the Centres needed to be given a chance to share their own ideas on potential projects run rather than having all projects prescribed by the centres.

\section{Monitoring of projects}

The level of skill for people assigned to monitor projects was a general concern to four participants. It was recommended that those people responsible for monitoring be trained in skills like sewing, working machinery, agricultural matters and so forth. For the participants this was an important factor in poverty alleviation, because what was happening at the time of the study was that social workers responsible for monitoring were perceived to focus more on production and less on the process and correct products that needed to be manufactured for profits to be made.

\section{CONCLUSIONS}

The main conclusion reached was that income-generating projects conducted at the two Development Centres seemed to be achieving their aims. However, there would appear to be room for improvement in terms of knowledge and skills imparted, and participation of beneficiaries in decision-making. The recommendations for improvements put forward by participants are endorsed by the authors of this paper. However, despite the fact that these strategies can potentially enhance the implementation of poverty-alleviation strategies, it is important to acknowledge that income-generating projects represent only one strategy for alleviating poverty and enhancing community development. Instead, a holistic, multi-pronged approach advocated by Davids, Theron and Maphunye (2009) needs to include income generation and job creation; attention to basic needs such as physical and social infrastructure including school and clinics; addressing social exclusion based on institutionalised racism and sexism; promoting sustainable livelihoods; and fostering human development through knowledge and skills.

\section{REFERENCES}

ALLRED, T.E. 1998. Privatising grassroots development: lessons learned from artisanal fishermen in Northern Columbia. Grassroots Development, (2):35-57.

BOND, P. 2003. Debates in local economic development policy and practice. Urban Forum, 14(2-3):147-164.

DAVIDS, I., THERON, F. \& MAPHUNYE, K.J. 2009. Participatory development in South Africa: a development management perspective $\left(2^{\text {nd }}\right.$ ed). Pretoria, South Africa: Van Schaik Publishers. 
DEPARTMENT OF WELFARE. 1997. White Paper for Social Welfare. Principles, guidelines, recommendations, proposed policies and programmes for developmental social welfare. Pretoria: Government Gazette.

DEPARTMENT OF SOCIAL DEVELOPMENT. 2006-2010. Five Year Strategy 2006-2010. Unpublished document.

DEPARTMENT OF SOCIAL DEVELOPMENT. 2006. Impact and effectiveness of poverty programmes in Gauteng. Unpublished paper.

DEPARTMENT OF SOCIAL DEVELOPMENT. 2007. Revised Operational Manual for Gauteng Province Development Centres. Unpublished document.

DEPARTMENT OF SOCIAL DEVELOPMENT. 2011. Draft Reviewed Framework for Developmental Social Welfare Services January 2011.

DEVELOPMENT INDICATORS. 2009. The presidency, Republic of South Africa. [Online] Available: www.thepresidency.gov.za/learning/me/indicators/pdf. [Retrieved: 12/05/2011].

DIMITRIEVSKA, V. 2008. Qualitative analysis of poor households in the Republic of Macedonia. Draft Document for the Guidelines for Identification of Household and Individuals in Dire Poverty with a view to Design and Implement appropriate Interventions to Improve their Situations. Unpublished Paper.

DU TOIT, M. 2006. The Darkest Africa. [Online] Available: http://www.theother sideofkim.com/index.php/tos/index1/C7/. [Retrieved: 28/08/2009].

HOLSCHER, D. 2007. Social work in times of neoliberalism: a postmodern discourse. Pretoria: Van Schaik Publishers.

HOLSCHER, D. \& SEWPAUL, V. 2006. Ethics as a site of resistance: The tension between social control and critical reflection. In: HALL, N. (ed) Social work: making a difference. Social work around the world. The year of IFSW's $50^{\text {th }}$ Jubilee. International Federation of Social Workers and Fafo. London: Sage Publications.

INTEGRATED SERVICE DELIVERY MODEL. 2006. Towards improved social services. Pretoria: Government Printers.

McLENNAN, B. 2007. SA to set official "poverty line". Mail and Guardian. [Online] Available: http: //www.Mail\&Guardianonline.htm. [Retrieved: 05/06/2007].

MIDGLEY, J. 1995. Social development: the development perspective in social welfare. London: Sage Publications.

MILLENIUM DEVELOPMENT GOALS REPORT. 2008. New York: United Nations.

MUBANGIZI, B.C. 2004. Poverty alleviation and service delivery: a case study for water programme in Mvenyane. Pietermaritzburg: University of KwaZulu-Natal. (Doctoral Thesis)

NOYOO, N. 2003. Social welfare policy, social work practice and professional education in a transforming society. Johannesburg: University of the Witwatersrand. (Unpublished PhD Thesis)

PATEL, L. 2005. Social welfare and social development. Cape Town: Oxford University Press.

PAUL, S. 1987. Community participation in development projects: the World Bank experience. Washington: The World Bank. 
PLAATJIES, D. \& NICOLAOU-MANIAS, K. 2005. Budgeting for job creation in social welfare services - exploring EPWP opportunities. Pretoria: Human Sciences Research Council.

PRETORIUS, T. \& DE LA REY, C.M. 2004. A brief introduction to research approaches in psychology. In: SCHWARTZ, L., DE LA REY. C.M. \& DUNCAN, N. (ed) Psychology: an introduction. Cape Town: University of Cape Town.

SACHS, J. 2005. The end of poverty: how we can make it in our lifetime. London: Penguin. SOUTH AFRICAN INSTITUTE FOR RACE RELATIONS. 2007/08. South African Survey. Johannesburg: Creda Communications.

SOUTH AFRICAN INSTITUTE OF RACE RELATIONS (SAIRR) 2011. South Africa Survey 2009/10. Johannesburg. SAIRR.

STATISTICS SOUTH AFRICA. 2011. Quarterly Labour Force Survey. Pretoria: Statistics South Africa.

STRYDOM, C. \& TLHOJANE, M.E. 2008. Poverty in rural area: the role of the social worker. Social Work/Maatskaplike Werk, 44(1):4-51.

SWANEPOEL, H. 2007. Community capacity building: a guide for field workers and community leaders. Pretoria: International Thomson Publishing.

TERRE'BLANCHE, M., DURRHEIM, K. \& KELLY, K. 2006. First steps in qualitative analysis. In: TERRE'BLANCHE, M., DURRHEIM, K. \& PAINTER, D. (eds) Research in practice: applied methods for the social sciences. Cape Town: University of Cape Town Press: 322-344.

VISSER, W. 2004. "Shifting RDP into GEAR". The ANC Government's dilemma in providing an equitable system of social security for the new South Africa. Paper presented at the $40^{\text {th }}$ ITH Linzer Konferenz, September 17.

WELMAN, J.C., KRUGER, S.J. \& MITCHELL, B.C. 2008. Research methodology. South Africa: Oxford University Press.

WILLIAMS, M., UNRAU, Y.A., GRINNELL, R.M. \& EPSTEIN, I. 2011. The qualitative research approach. In: GRINNELL, R.M. \& UNRAU, Y.A. (eds) Social work research and evaluation: foundations of evidence-based practice $\left(9^{\text {th }}\right.$ ed). New York: Oxford University Press: 52-67.

WORLD BANK. 1992. World Development Report: the state in a changing world. Washington DC: Oxford University Press.

ZUNGU, Z.M. 2006. An investigation into factors contributing to the success or failure of income generation projects in Nongoma. KwaZulu-Natal: University of KwaZulu-Natal. (Master's in Social Work research report)

Ms Innocentia Raisibe Kaeane, South African Social Security Agency (SASSA), Sedibeng District, Vereeniging; Prof Eleanor Ross, Centre for Social Development in Africa, University of Johannesburg, South Africa. 